\title{
Research on the open teaching of College English based on network technology
}

\author{
TIAN Pinjing 1, a \\ ${ }^{1}$ Jilin Business and Technology College, Changchun 130000, China \\ aemail: tianpinjingj|@163.com
}

Keywords: Interactive; teaching platform; English Teaching

\begin{abstract}
With the continuous development of information technology and network technology, using modern information technology to assist in the traditional form of teaching is becoming more and more important. In this paper, the in view of the problems existing in the current college English teaching, which makes use of the network advantage, planning and design a effectiveness, interaction and flexibility of network teaching platform. Broke the traditional teaching model in the time and space constraints, to make up for the lack of teachers in a unified teaching mode can not only enhance the students' autonomous learning enthusiasm, improve their learning efficiency, also help teachers understand the students of master degree course, timely adjustment and remedial teaching.
\end{abstract}

\section{Introduction}

With the improvement of modern science and technology development and the development of network technology, network teaching using information technology to overcome the drawbacks of traditional education by time and space constraints, making the majority of teachers and students can be asynchronous to complete the interactive teaching activities. With the rapid development of the computer network, the limitation of traditional education resources and teaching methods have been broken. Teachers can according to their own teaching experience in the design of the curriculum and the teaching platform to collect teaching effect, students can according to their own learning plan and schedule arrangements, to implement the personalized, autonomous learning. Network teaching is also able to achieve the sharing of educational resources, has a good interaction, has become an inevitable trend of modern education[1].

\section{Research on College English Teaching}

Put forward along with the development of society and the new college English teaching reform, the traditional teaching methods can not meet the needs of modern English teaching. In the traditional teaching, the students tend to read words, read the article as the only way to learn English, but only focus on single skill training is not enough, it should be the coordinated development of knowledge, ability and quality, comprehensive training as the aim of College English teaching, which demands the corresponding teaching methods and to adapt. At present, College English teaching has not only did not dilute the color of the exam oriented teaching, but there is a trend toward the direction of the development of the four six levels of examination. The four six level test is only a focus on reading and spelling, and ultimately led to the use of language teaching can not achieve the purpose. The number of hours spent in foreign language teaching does not match with the actual results. However, most students are not more proficient in reading foreign books, in particular, do not understand, can not speak, it is difficult to communicate with foreigners directly. In view of the main problems existing in College English teaching, we should take some measures from the aspects of teaching concept[2], teaching content and course system, teaching method and teaching means.

(1) increasing the interaction between teachers and students, in the traditional college English teaching, teachers except in the classroom to teach knowledge through questions, link and students 
communicate, besides rarely and students were interaction, students have questions or ideas, can not be timely and teachers in communicating, especially students in general is more love face embarrassed him face to face, to ask the teacher questions, resulting in even if the problem can not be timely interaction.

(2) to update teaching content, College English teaching content involves imparting language knowledge, language skills, expand communicative language ability etc., its essence and not pay attention to the examination and take the cramming method of teaching, only pay attention to the test level, redo, while ignoring through the training of listening and speaking practice to communicate with people, its ultimate goal is through English language teaching the students to use English ability training to also can be listening, speaking, reading and writing of the Almighty and non English as "deaf" or "dumb" to maximize the students to create the potential to dig out.

(3) to improve the teaching means, the modernization of teaching means plays an important role in improving the quality of teaching. Nowadays, it has become a symbol of the reform of English teaching means to promote the modernization of multimedia based teaching. Shanghai Jiao Tong University in the relevant publications on the campus beauty of the great efforts to make multimedia courseware, and in the school to promote the use of large-scale experience, their practice is worth learning from. And how to promote the modernization of foreign language teaching, we can now use the most popular network technology, to strengthen the interaction in English teaching, and enhance the form of teaching performance.

\section{System design principles}

In China, based on network and Multimedia College English new teaching mode and students how to effectively utilize resources of the network of autonomous learning has attracted widespread attention in the universities, the research work has already started, at home in the new mode of learning theory has become a system, colleges and universities have built based on the network self-regulated learning environment and attempt of the reform of College English teaching, and begun to take shape. But with the development of new teaching mode, it also produced a series of new problems.

Research results: since the 90 s of last century, with the application of computer assisted language teaching, multimedia network teaching into the College English classroom. With the deepening of the reform of College English in China, based on network teaching mode of College English is colleges and universities gradually extended, all colleges and universities have established campus network, site of foreign language teaching, network technology involved in College English classroom teaching, its interactivity and diversity to teachers for classroom teaching provides a broad space to display their talent. Its unique advantages are: the teaching resources can be greatly expanded. The network teaching provides the possibility for the true meaning of individual learning. Students can study at any place and at any time. And according to their own level and need, free choice of different levels and levels of learning materials. Can set their own goals, by self feedback information immediately know their learning outcomes, identify problems, to timely adjust their difficulty in learning and progress. Network teaching students and teachers and students can also through the BBS forum, e-mail, chat rooms, and other ways to communicate in class and class. This autonomous learning process has changed the traditional teaching methods of a teacher to teach dozens of students, help to stimulate students' learning interest and potential, improve the ability of autonomous learning. Whether it is multimedia technology. The development and use of computer assisted instruction, or the development and utilization of network technology, have brought revolutionary changes to the English teaching, which has optimized the structure of College English classroom[3].

Although new teaching model with the traditional teaching mode incomparable advantages, but on the present teaching situation of our country also exist some shortcomings: in our country at present the popularity of computers and computer technology college students rate is still very low, can not really play by making full use of the advantages of advanced network resources anytime and anywhere teaching and students' autonomous learning. Another aspect of the network of 
English teaching resources still exist many problems, such as teaching resources of the network is too fragmented, English teaching resources of the network is not systematic, complete, do not pay attention to comprehensive training, this is the College English teaching reform facing the new problem to be solved.

Zero hours of listening teaching evaluation is very important, we mainly adopt the usual monitoring students' learning progress, and then in the stipulated time, different levels of test, formation usually results, in the final to test level. We conducted a pilot of 04 class students, after gradually open hearing of "zero hour" teaching. The university English four, six level examination results, for example, 04,05 and 06 students pass rate reached $65 \%, 78 \%$ and $86 \%$ respectively, time statistics are the sixth semester, the fifth term and the third term in previous students reflect the listening part difficult situation under, students' listening score is to improve the fastest. Although there are some differences in the learning of the three grades, the learning effect is clear. The following is the three grade in the first grade in the final grade distribution.

Human society has entered the information age, the rapid development of information technology, not only penetrate into all walks of life, but also to the education put forward the challenge. The coming of knowledge economy calls for the innovation and profound change of education. The emergence of the Internet, but also for the English teaching has brought unprecedented opportunities for students to create a diverse learning environment, providing access to authentic English opportunities. So, how to use the network resources for English classroom teaching? , is placed in front of each of our teachers is an important issue facing the Internet rich and colorful language materials, English teachers how to change teaching methods, try the new teaching model, promote the optimization of the learning process, to help students in the online travel guide students according to the need for independent learning and to obtain the necessary knowledge of English. Below I will according to themselves in recent years of teaching practice and observation to the students learning process of feedback, talk about bit of experience, have a wrong place, hope to hearing.

\section{Make full use of network resources}

Einstein said: "interest is the best teacher." Confucius also said: "those who know better than the good, good as happy person." English teaching, but cannot do without interest and sensory stimulation. There is no doubt that the development and use of multimedia cyber source, the vitality and vigor into language teaching. Especially speaking, animation, combination of text and image, mobilize Students'senses, motivate and cultivate the students' interest and actively participate in the whole process of teaching. In many teaching in, I had to guide students use Kelihua preparation system and Tsinghua Tongfang database provided information, viewing the electronic text, video and audio files, perception of teaching content, review the main points in the text, to imitate the standard pronunciation and intonation, to consolidate training, so as to enrich, broaden the students knowledge, stimulate students curiosity and thirst for knowledge, also makes the classroom to present the diversity, the effect is very good. Such as in the "country music" a class, I use the students' curiosity, computer media to produce information about all kinds of music, to attract students' attention, from the sound to stimulate students' listening, to produce pictures, stimulate students' senses[4], let students clear the central goal of this section to learn, then ask the students to adopt cooperative learning group and way to learn some new words and sentences according to the knowledge of the network. Guide the students themselves through the network query, spelling words, sentences aloud. The dialogue performances, games, through the network of independent learning, ability to gather and collate information. I was assigned to the students of the learning task, the task of classification, encourage them to group as a unit, independent of query answers from the Internet, access to information. And make records and report according to the group, communication in class. The students not only master a number of autonomous learning in the network environment, and make their initiative to get a real play. In the study at the beginning of this unit, to arouse students' interest and let students understanding of music, the teacher can prepare in advance some music, such as: rock music, country music, light music, symphony, folk music, and 
so on. In class released these fragments allow students to judge what is music. In studying the text, and strive to enable students to appreciate to the mentioned in the book of folk music, African music and Mediterranean music and jazz, listen and let the students talk about the characteristics of every kind of music, to enable students to better understand the music inherent meaning. After completion of the text and ask the students to supplement the music content, the best in the group as a unit, to encourage students through the Internet to find more information, graphics and appearance, it is best to sound material, and communication in the classroom.

Practice has proved that the classroom teaching mode under the network environment, students ushered into a relaxed, pleasant atmosphere, can play to their imagination and creativity. Use of network optimization and combination of information, which can make the indirect for directly, become boring interesting, reduce or even eliminate interference, stimulate the students' learning interest and thirst for knowledge, enhance students' sense of participation and intimacy, make learning become the students an urgent need and not mental burden, providing apartments enjoy learning learning environment.

The information resources in the network environment are always open, the communication media is more and more communication; the transmission system is multimedia; knowledge is limited by time and space. These characteristics determine that the teaching process in the network environment must be open, interactive, and independent. With the development of modern educational technology[5], more and more teaching aids into the classroom, rich resources greatly stimulated the students' senses, aroused interest in their learning, so that students from passive for active, from "want me to learn" to "I want to learn". The classroom teaching more lively and vivid, better teaching effect.

\section{Conclusion}

Based on network environment interactive College English teaching mode is the trend and direction of the reform of College English teaching, this kind of new teaching mode emphasizes the organic combination of classroom and computer network two teaching environment, the whole teaching process with face-to-face teaching in classroom and online autonomous learning teaching both ways. Using the advantage of computer network to speed up the reform of College English teaching, and building a bridge between the classroom teaching and the network independent learning, which greatly enriched the teaching methods of College english.

\section{References}

[1] Zhuang Zhixiang, Huang Wei, Wang Le. Current situation and Prospect of [J]. foreign language teaching multimedia foreign language teaching in China, 2007 (1).

[2] Li Xiaoxiang. Stage of College English teaching reform of achievements and thinking [C]. Chengdu: University, Ministry of education, English teaching reform expert tour. 2006. 10.

[3] Wang Xiaolei. Study [J]. Heilongjiang science and technology information of independent research students under the network environment, 2008 (1): 142

[4] Xiao Liangrong, Yu really. On the opportunities and challenges and [J]. language of computer network technology brings to the teaching of College English, 2002

[5] Shen Yinzhen. Multi culture and Contemporary English teaching [M]. Hangzhou: Zhejiang University press, 2006, (3): 92 